\title{
13
}

\section{An Asian school of strategic studies?}

\author{
Amitav Acharya
}

I have been asked to comment on the topic: 'An Asian school of strategic studies?' I understand this question as asking whether there can be a school in Asia that represents or reflects a distinctive approach to strategic studies like the English school on international relations theory or the Copenhagen school on security studies. I am glad that there is a question mark with the topic, because one could have some serious doubts about such an idea. Posing the question is very useful for provoking a discussion about some of the big challenges and questions that confront the development of strategic studies in Asia or the Asia-Pacific to which the Strategic \& Defence Studies Centre (SDSC) has made a very significant contribution. Let me raise five supporting questions and challenges; the first three are familiar and perhaps not really critical. I mention them briefly. The last two are really crucial.

First, which region? What or where is Asia? We all know that Asia is not a given or fixed concept but one rather malleable as befits an area of multiple contested histories and, more importantly, of immense physical, cultural and political diversity. ${ }^{1}$ Regional naming keeps changing. New names keep popping up like a fashion statement. In the past three decades, we have seen an institutional naming shift from 'Asia Pacific' to 'East Asia'

1 Amitav Acharya, 'The idea of Asia', Asia Policy, no. 9, 2010, pp. 2-39. 
as evident in the shift from Asia-Pacific Economic Cooperation (APEC) in 1989 to East Asia Summit in 2005. We have seen the emergence of 'Indo-Pacific' in the past few years, although there is no institution as yet to celebrate it nor agreement on its merit. ${ }^{2}$ Regional naming is itself a very political affair as it decides which country or subregion is included or excluded and what kind of security issues become the organising theme for a school of strategic studies. It also begs the question: who is to name the region? In the past, region-naming has been done mostly by great powers. British hegemony is associated with the term 'Far East' while the United States is associated with 'the Pacific' or the 'Pacific Rim'. Who has the power to rename it now? Perhaps China, which is reviving the Sinocentric idea of the Silk Road as part of its One Belt, One Road (OBOR) initiative. But this is not going to be acceptable to Asia's other leading powers, notably India and Japan.

Second, strategic studies or security studies? There has been much redefinition of the concept of security since the end of the Cold War. Strategic studies is mainly concerned with the use and threat of use of military force. Security studies is much broader and embraces nontraditional security and human security. While strategic studies is criticised for being too narrow, security studies is often accused of becoming too broad to have coherence or utility. Lately, there has been a good deal of talk about the 'return of geopolitics'. In a 1991 essay, Stephen Walt spoke of a 'renaissance' of 'security studies'. ${ }^{3}$ Might there now be a similar renaissance of strategic studies, especially after the election of Trump and his threat to start a new nuclear arms race? Surely military threats have not disappeared. Yet security is in the eyes of the beholder, and the idea of comprehensive security has roots too deep in Asia to be sidelined in favour of military strategic studies.

Third, who is to lead or anchor an Asian school? Where might the intellectual leadership and institutional anchoring of an Asian school come from? Can Australia and The Australian National University's SDSC provide such leadership now? For some time, it has been the premier institution providing de facto leadership in the academic

2 For contrasting views on the utility of the Indo-Pacific as a concept, see Rory Medcalf, 'The IndoPacific: What's in a name?', American Interest 9, no. 2, 2013; and Andrew Phillips, From Hollywood to Bollywood? Australia's Indo/Pacific Future in a Contested Asia, Australian Strategic Policy Institute, Canberra, 12 October 2013.

3 Stephen M. Walt, 'The renaissance of security studies', International Studies Quarterly, no. 2, 1991, pp. 211-39. 
training for strategic studies in the Asia-Pacific region. But to do so overtly now might be controversial politically and impede much-needed indigenisation — or the need for more local Asian voices and scholarship. But are institutions and scholars from the region up to the task? What about universities or think tanks in Japan? China? India? South-East Asia? Singapore? Each is problematic, although for different reasons, ranging from lack of resources to lack of academic freedom.

It is revealing that some of the best strategic/security studies experts from Asia do not live and work in Asia but in the United States, Europe and here in Australia. Sometimes this is not from choice or for lack of resources but because of a lack of hospitable academic environments and academic freedom in Asian countries.

Although the above three questions are important, addressing them depends on how one deals with the last two questions. One is an intellectual question. The other political.

First, a school needs a core thematic focus and a set of generalisable concepts and methods. It is the idea of a society of states and a whole range of concepts built around it for the English school. For the Copenhagen school, it is the idea of securitisation and desecuritisation.

What could be a comparable focus for an Asian school? Could it be culture or strategic culture? I am reminded of Desmond Ball's seminal article, 'Strategic culture in the Asia-Pacific region'. ${ }^{4}$ It identified distinctive aspects of strategic culture in Asia, some of which are:

- an Asian way of war, with less emphasis on holding territory than other forms of military, economic and cultural hegemony

- informality of policy-making structures and processes

- consensus over majority rule

- pragmatism over idealism

- a comprehensive approach to security.

But putting culture at the heart of strategic studies brings back bad memories such as 'Asian values', the 'Asian view of human rights' or Asianstyle democracy. These ideas were criticised as being too 'relativist' and,

4 Desmond Ball, 'Strategic culture in the Asia-Pacific region', Security Studies 3, no. 1, 1993, pp. 44-74. 
even worse, as a justification for authoritarianism in such Asian countries as Singapore, Malaysia and China. At the very least, they smacked of too much reification, which could not be supported in view of Asia's political diversity.

To be sure, each country or region is distinctive. All theories and schools of international relations or strategic studies reflect a national or regional context. But they must do more. I have a simple test for any national or regional school: it must explain not just what happens in that country or region. A school must also generate ideas that can travel beyond them. It must have a general or universal applicability.

Take for example the English school or the Copenhagen school. To be sure, both can be viewed to some extent as being rooted in and reflecting the distinctive historical and political context of Europe. I suspect the former (especially its early version) might even reflect a nostalgia about Europe's lost empires and what it saw as Europe's largely benevolent contribution in creating a rule-based international society (albeit with European rules). Similarly, the Copenhagen school and its securitisation theory cannot be delinked from continental Europe's own intellectual traditions, including post-structuralism or discourse analysis.

But the concepts and methods from both the English and Copenhagen schools have a general universal applicability, however limited and contested. They have been usefully applied to East Asia and other parts of the world. What might an Asian school of strategic studies offer in this area?

Take for example the Chinese school of international relations, perhaps the most prominent of the emerging national approaches to the study of international relations and strategy in Asia today. So far, much of the Chinese school is based on the Chinese culture, worldview and foreign policy behaviour-past, present and future. Moreover, a good deal, if not all of it, seems like a legitimisation of the Chinese official foreign policy ideology such as the Tianxia ('all under heaven') and the 'peaceful rise' of China. It has yet to offer a set of concepts and approaches that can travel beyond China or its immediate East Asian regional environment and be used to study international relations in general or in other regions of the world. So it has yet to pass my aforementioned test of a valid national or regional school. 
The last but most important challenge is what we might call the 'Hedley Bull test' for the relations between academics and governments. This was contained in an essay by Bull in 1972 when he was still teaching at The Australian National University. Here Bull wrote:

The academic International Relations specialist ... should not be a servant or agent of his government ... There is a need on both sides for exchange of ideas and mutual criticism between academics and officials in the field of foreign policy and defence ... But inquiry into International Relations is a different activity from running the foreign policy of a country and necessarily clashes with it. ${ }^{5}$

Bull further held that:

International Relations specialists in universities and in governments should talk to each other but should remain themselves ... It is only if they remain themselves that academic students of International Relations are likely to have anything distinctive to contribute to the discussion of foreign policy problems. ${ }^{6}$

Bull could not have missed the fact that strategic studies everywhere had always been policy-oriented and enjoyed close proximity to governments. The distance is quite blurred in the United States, so much so that there is a veritable 'revolving door' between the world of academia and officialdom. Ironically, there has been some concern of late in the United States about an alleged academia-policy gap ${ }^{7}$ or the lack of adequate interaction between the academic and policy worlds. But as I have argued, the situation is the reverse in Asia: the relationship is too close and goes too far. ${ }^{8}$ How many scholars in Asia, especially those working in think tanks, but also many in the universities, would meet this Hedley Bull test? Not many, in my view.

I would add a corollary to the Hedley Bull test. This is called 'entrapment', a concept outlined in an essay I published in 2011 based on more than a decade of experience in developing strategic studies and international

5 Hedley Bull, 'International relations as an academic pursuit', Australian Outlook 26, no. 3, 1972, pp. 251-65.

6 Ibid.

7 Nicholas Kristof, 'Professors, we need you', New York Times, 15 February 2015.

8 Amitav Acharya, 'Narrowing the academia-policy divide in international relations', East Asia Forum, 20 May 2014, www.eastasiaforum.org/2014/05/20/narrowing-the-academia-policy-dividein-international-relations/ (retrieved 1 February 2018). 
relations in Asia. ${ }^{9}$ Entrapment occurs when scholars, after having provided intellectual input at an early stage of policy-making in a particular area, remain beholden to the choices made by officials and thereby become unwilling to or incapable of challenging officially sanctioned pathways and approaches for fear of losing their access and influence. Although that essay focused on regionalism, it is also true of security and strategy. The danger of entrapment is present universally where scholars and policymakers interact in a close and sustained manner.

This has unfortunate consequences, especially for the academic development of strategic studies and international relations. As I observed during my long association with Asian think tanks and universities, too many well-trained scholars are unable to avoid the temptations to become involved in policy work and thereby lose their academic edge. This in turn has been a major cause of the absence or underdevelopment of theoretical work, which is required for the emergence of any credible and sophisticated Asian school of international relations and strategic studies (whether at national or regional levels). Hence my argument was and remains that in Asia the academia-policy gap in strategic studies needs to be widened, not further narrowed.

Why do Asians fail the Hedley Bull test? Why does entrapment occur? To begin with, the primary stakeholders and consumers of strategic studies knowledge in Asia are governments, not the academic community or civil society. In fact, strategic studies in Asia is dominated not by universities but by think tanks that are closely tied to the governments or establishment forces (including some placed at universities deliberately to draw in academics and sometimes to control or entrap experts in strategic studies). Some examples here would be several members of the ASEAN-ISIS (Association of Southeast Asian Nations Institutes of International and Strategic Studies, a group of think tanks and institutes from each of the ASEAN countries, some but not all of which are based in universities); the Institute of Defence and Strategic Studies (IDSS) at the Nanyang Technological University, Singapore; the Institute of Defence

9 Amitav Acharya, 'Engagement or entrapment: Scholarship and policy-making in Asian regionalism', International Studies Review 13, no. 1, 2011, pp. 12-17. The author was Deputy Director and Head of Research of the Institute of Defence and Strategic Studies (IDSS) in Singapore between 2001 and 2007. IDSS became the S. Rajaratnam School of International Studies in December 2006 and remains Asia's largest university-based think tank and school in strategic studies, although its scope extends to other areas of international relations, including political economy and international relations. 
Studies and Analysis (IDSA) in India; the Korean Institute for Defence Analysis (KIDA) in South Korea; and the National Institute for Defence Studies (NIDS) in Japan. There are also numerous such thinks tanks and research institutes in China that do research on strategic studies, such as the China Institute of International Studies (CIIS), the China Institutes of Contemporary International Relations (CICIR), China Institute for International and Strategic Studies (CIISS), and the various centres and Institutes of the Chinese Academy of Social Sciences (CASS), to give but a few examples. Many of these strategic studies think tanks are extensions of defence or foreign ministries and/or directly funded by them and run by retired or seconded bureaucrats. University-based or genuinely independent research centres on strategic studies in Asia are rather few and far between. Even these are often subject to government control and manipulation, overtly or indirectly, either through funding, fear or both, especially in Asia's authoritarian countries. Some of these institutions are ranked very highly, such as in the 'Global Go To Think Tank Index' produced by the Think Tanks and Civil Societies Program (TTCSP) at the University of Pennsylvania, despite having little or no academic freedom or having a record of actively suppressing it. Apparently, academic freedom or freedom of expression is not taken into consideration in the TTCSP's rankings (or in the university league tables), which means think tanks and universities from well-resourced but highly authoritarian states can secure high ranking and thus legitimise themselves. ${ }^{10}$

As noted, one consequence of government or stakeholder interference is the discouragement of high-quality theoretical or conceptual work. Many policy-makers in Asia see conceptual/theoretical work or academic training in international relations and strategic studies as irrelevant or a waste of time for foreign policy-making. Yet such work is crucially needed for broadening policy choices and developing alternative ideas without which strategic studies would be impoverished.

10 In the 2015 'Global Go To Think Tank Index', the China Institutes of Contemporary International Relations (CICIR), a think tank directly under China's State Council, was placed at number 6 in the 'Top Foreign Policy and International Affairs Think Tanks' category ahead of the Woodrow Wilson International Center for Scholars (United States) and International Institute for Strategic Studies (IISS; United Kingdom), while the China Institute of International Studies (CIIS) was at 28. James G. McGann, 2015 Global Go To Think Tank Index Report, University of Pennsylvania Think Tanks and Civil Societies Program, 9 February 2016 (see p. 87), repository.upenn.edu/cgi/ viewcontent.cgi?article=10098context=think_tanks (retrieved 1 February 2018). The Chinese Academy of Social Sciences (CASS) was named the top think tank in Asia by Foreign Policy magazine for 2009. 'The Think Tank Index', Foreign Policy, undated, web.archive.org/web/20090119095446/ http://www.foreignpolicy.com/story/cms.php?story_id=4598\&page=3 (retrieved 1 February 2018). 
In Asia, a key function of strategic studies think tanks is to engage in Track-II activities, in which academics and policy-makers in their private capacity exchange ideas and develop policy directions. As Professor Stuart Harris from The Australian National University wrote in 1994, TrackII dialogues in Asia are dependent 'upon the consent, endorsement and commitment, often including financial commitment, of governments'. ${ }^{11}$ One might add to this the frequent presence and dominance of governmentlinked scholars or retired government officials in such dialogues. While they are supposed to speak in their private capacity, most often they end up presenting their government's line. At the same time, non-conforming social movements and independent academics are general excluded from Track-II dialogues in Asia.

Another problem is the influence of generalists in Track-II strategic dialogues, those who lack expertise in specific issue areas such as maritime or environmental protection. And there is much generational gatekeeping in these dialogues or the failure to bring in new faces or new blood. The result is that Track-II dialogues in Asia are unable to rise above national interests and present alternative understandings of strategy and foreign policy. They are unable to call for fundamental reforms and transformation in the region by overcoming the trap of nationalism, state sovereignty and non-intervention.

What is to be done, if anything? Instead of an Asian school, I would call for more networking-especially among universities and think tanks in Asia, the Asia Pacific, Indo-Pacific or wherever-with a view to exchanging ideas, information and solutions to common problems. This can be done at multiple levels. Track-II can be one of them. It is here to stay. But clearly there cannot be a credible Asian school of strategic studies that relies primarily on policy think tanks. Other initiatives are needed. One such initiative can be among students, like Evelyn Goh's graduate network.

11 Stuart Harris, 'Policy networks and economic cooperation in the Asia Pacific', Pacific Review 7, no. 4, 1994, p. 390. 
A fitting model is the now defunct Canadian Consortium for Asia-Pacific Security (CANCAPS), which emerged in the 1990s. ${ }^{12}$ Although funded by Canada's Department of Foreign Affairs and International Trade, renamed now as Global Affairs Canada, it was led and managed by academics. The venues of its conventions changed across Canada. Participation was open to all and mainly consisted of academics. But government officials participated in droves and with enthusiasm but without any effort to control the flow of opinion. It functioned more as a professional association for scholars and policy-makers interested in security issues in the Asia-Pacific.

In developing any strategic or security studies network, it is important to develop some core themes, especially non-traditional security (NTS). NTS could bridge the gap between traditional strategic studies and a more expansive notion of security studies. Another key area would be negotiations and conflict resolution, which have not been developed well in Asian universities and think tanks.

It is crucial for strategic studies scholars to engage in historical and theoretical research, not just policy research. To quote Hedley Bull again:

The test for an academic contribution to International Relations is that it should have either historical or theoretical depth. Academic work which consists simply of the retailing of information about international affairs, or of ad hoc comment of policy polemic, does not meet the test. ${ }^{13}$

Again this is lacking in Asia, where policy-makers distrust or disparage theoretical work and academics working within different incentive structures find no benefit from it.

Finally, strategic studies institutions and scholars should engage in genuine policy debates and explore alternative ways of promoting security. The role of strategic studies in many, if not all, think tanks in Asia is limited largely to providing background information to policy-makers rather than debating and advocating different policy positions or publicly contesting government positions. This should change if strategic studies is to have a modicum of credibility, even as a mainly policy-oriented enterprise.

12 The author served as one of the directors of CANCAPS. For an example of its work, see Marius Grinius, 'Canada and Asia: Prosperity and security', Canadian Global Affairs Institute, policy paper, June 2015, d3n8a8pro7vhmx.cloudfront.net/cdfai/pages/569/attachments/original/ 1436386569/Canada-Asia_Prosperity-Security.pdf?1436386569 (retrieved 1 February 2018).

13 Bull, 'International relations as an academic pursuit', p. 264. 
To sum up, the development of strategic studies in Asia must add independent and critical perspectives. This would require rising above national positions and perspectives in Track-II dialogues and debates. It would also require the emergence of genuine epistemic communities in functional areas organised around knowledge rather than official connection, and greater sensitivity to dissent and alternative voices from social movements. It demands nurturing and co-opting new generations of scholars. There is also a need for scholarly associations of Asian academics who study regionalism and are independent of government sponsorship. What the region needs is a free flow of policy ideas and agenda-setting for truly transformative cooperation.

Notwithstanding my reservations about an Asian school, let me conclude by stating what I consider to be the exemplary combination of academic rigour, scholarly independence and policy relevance that can serve as the inspiration for Asian security studies experts and scholars, and even a school, should there be an effort in that direction. One needs to look no further than the work of Desmond Ball, who passed away shortly after the SDSC 50th anniversary conference. Des Ball's work was scholarly at the highest level, especially his contributions first to nuclear strategy, then to Asia-Pacific regional security. It is also striking that his early and pioneering work on national security and nuclear strategy, especially on the US military bases on Australian soil, was extremely critical of the US and Australian government policies. Indeed, it was a bible for a generation of peace activists in Australia, as I knew personally when I was a student in Perth in the 1980s. This suggests his integrity and independence. As the Cold War ended, Des Ball's work shifted to Asia-Pacific regional security issues. This corpus of work provided an invaluable contribution to the thinking and approach of governments and of the policy community of the region as they embarked on initiatives to build new regional cooperative security institutions, such as the ASEAN Regional Forum. ${ }^{14}$ Despite this, Des Ball continued to assert his independence, challenging and embarrassing governments that he saw as perpetrating oppression (as in Myanmar and Indonesia) or failing to offer public transparency and accountability, as seen with the revelations about

14 I was fortunate to be a collaborator in Des Ball's work on Asia-Pacific multilateralism, especially that on preventive diplomacy. See Desmond Ball and Amitav Acharya (eds), The Next Stage: Preventive Diplomacy and Security Cooperation in the Asia-Pacific Region, Strategic \& Defence Studies Centre, The Australian National University, Canberra, 1999. 
US military bases in Australia and later (in 2001) Singapore's alleged intelligence operations in Australia. ${ }^{15}$ If Asian scholars can achieve this sort of intellectual courage and integrity against the backdrop of engaging in outstanding scholarship, I will withdraw my reservations on an Asian school of strategic (or security) studies.

15 Catherine McGrath, 'Claims of Singaporean spying', $A M$, 9 August 2001, www.abc.net.au/am/ stories/s343479.htm. 
This text is taken from New Directions in Strategic Thinking 2.0:

ANU Strategic \& Defence Studies Centre's Golden Anniversary

Conference Proceedings, edited by Dr Russell W. Glenn, published 2018 by ANU Press, The Australian National University, Canberra, Australia. 